\title{
Hemiancistrus guahiborum, a new suckermouth armored catfish from Southern Venezuela (Siluriformes: Loricariidae)
}

\author{
David C. Werneke*, Jonathan W. Armbruster**, \\ Nathan K. Lujan*, and Donald C. Taphorn***
}

Hemiancistrus guahiborum, new species, is described from the Orinoco River drainage of Venezuela. Hemiancistrus guahiborum can be separated from all other Hemiancistrus and all Peckoltia except P. braueri and P. cavatica by having an orange edge to the dorsal and caudal fins. Hemiancistrus guahiborum can be separated from Peckoltia cavatica and P. braueri by having the dorsal fin with separated light spots or uniformly colored ( $v s$. with dark spots forming bands) and the sides either solidly colored or with tan blotches (vs. with dark dorsal saddles).

Hemiancistrus guahiborum, espécie nova, é descrita para a bacia do río Orinoco na Venezuela. Se distingue de todas as espécies de Hemiancistrus e Peckoltia, com exceção de Peckoltia cavatica e P. braueri por possuir uma franja alaranjada no bordo das nadadeiras dorsal e caudal. Se distingue de P. cavatica e P. braueri por possuir a nadadeira dorsal com colorido uniforme ou com manchas claras, e por possuir as laterais do corpo de cor uniforme ou com manchas claras.

Key words: Ancistrini, Hypostominae, South America, Systematics.

\section{Introduction}

Loricariidae is the largest family of catfishes, and its largest subfamily is the Hypostominae. Four of the tribes of the Hypostominae (Corymbophanini, Hypostomini, Pterygoplichthini, and Rhinelepini) account for just six of the 30 currently recognized genera of the subfamily, with the Ancistrini making up the 24 remaining genera (Armbruster, 2004). Most of the genera of the Ancistrini are well diagnosed, with the prominent exceptions of Hemiancistrus and Peckoltia, which are polyphyletic and without distinct diagnoses (Armbruster, 2004). This is especially problematic because many of the undescribed species of hypostomines that were discovered recently have been assigned to either Hemiancistrus or Peckoltia because they lack the derived characteristics of other ancistrin genera (see Cardoso \& Lucinda, 2003; Armbruster, 2003; Armbruster $\&$ Werneke, 2005). In general, the one character that could potentially separate Hemiancistrus and Peckoltia is that Hemiancistrus typically has spots and Peckoltia typically does not, but this is hardly an adequate diagnosis. There are notable exceptions in the current taxonomy, and more work needs to be done to separate the two genera.
The western side of the Guyana Shield in Venezuela has been the subject of several major collecting expeditions in the past 20 years, and these trips have revealed a bounty of undescribed species of the Loricariidae. One such species is described herein as Hemiancistrus guahiborum (Fig. 1), which is known from several hundred specimens taken from tributaries of the upper and middle Orinoco River. Armbruster (2004) examined the osteology of $H$. guahiborum (identified therein as Hemiancistus sp.) and found that it formed a basal polytomy with $H$. micromattos (labeled as Peckoltia oligospila), P. sabaji (labeled as Peckoltia sp. big spot) and a clade consisting of all other species of Peckoltia, Acanthicus, Hypancistrus, Leporacanthicus, Megalancistrus, Panaque, Pseudacanthicus, and Spectracanthicus.

\section{Material and Methods}

Counts and measurements follow Armbruster (2003). Specimens were cleared and stained for examination of bone and cartilage following the methods of Taylor \&Van Dyke (1985). Names of plate rows follow Schaefer (1997). The following are abbreviations used in the text: $\mathrm{D}=$ distance, $\mathrm{Dia}=$ diameter,

*Department of Biological Sciences, 101 Cary Hall, Auburn University, AL 36849-5407, USA. e-mail: (DCW) wernedc@auburn.edu; (NKL) lujannk@auburn.edu

**Department of Biological Sciences, 331 Funchess, Auburn University, AL 36849-5407, USA. e-mail: armbrjw@auburn.edu

***UNELLEZ, Mesa de Cavaca, BioCentro, Museo de Zoología, Colección de Peces Guanare, Estado Portuguesa 3310, Venezuela. e-mail: taphorn@cantv.net 


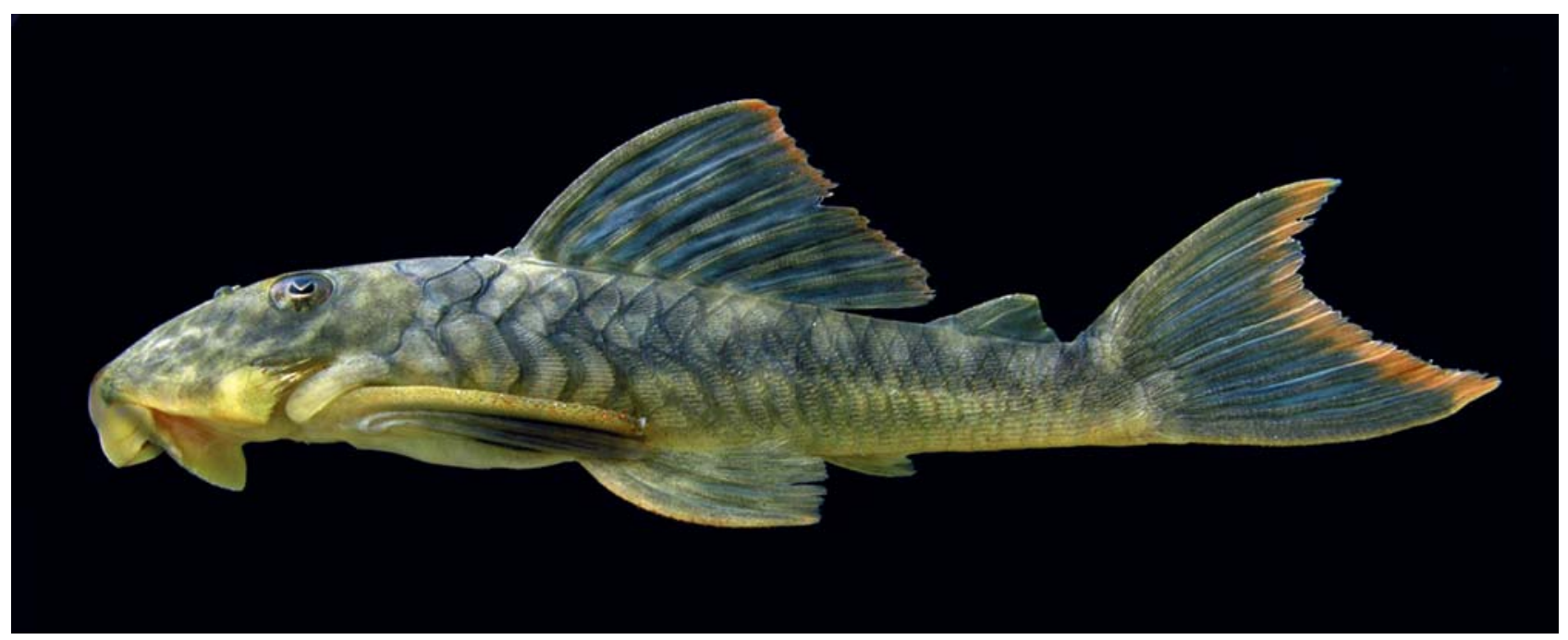

Fig. 1. Live specimen of Hemiancistrus guahiborum, AUM 42941, 69.6 mm SL, río Orinoco. Photo by M. H. Sabaj.

$\mathrm{Dp}=$ depth, $\mathrm{dr}=$ drainage, $\mathrm{L}=$ length, $\mathrm{W}=$ width, $\mathrm{SL}=$ standard length. Museum acronyms follow Leviton et al. (1985). Comparative specimens examined are listed in Armbruster $(2003,2004)$ and Armbruster \& Werneke (2005). When present in materials examined first number in parentheses represents the number of specimens measured followed by the range of standard lengths of the specimens. Specimens were sampled broadly within the type series and the non-types, but given the large number of specimens available, not all specimens were measured or examined for meristics. Measured specimens have numbered points inserted into their gill openings. The type locality was restricted to the río Ventuari because of the many specimens available from this region and to avoid any future problems from researchers that might want to split the species.

Gut contents were examined by dissecting the viscera from the peritoneal cavity of one individual from each of three lots. The viscera were removed as a unit by cutting the esophagus immediately posterior to the ventral processes of the complex centrum, and the posterior intestinal tract immediately anterior to anus. Anterior $100 \mathrm{~mm}$ of gut was dissected to expose gut contents.

\section{Hemiancistrus guahiborum, new species} Figs. 1-2

Holotype. MCNG 51994, 106.9 mm SL, Venezuela, Amazonas, río Ventuari at raudales Tencua $56 \mathrm{~km}$ ESE of San Juan de Manapiare, $05.04968^{\circ},-065.62722^{\circ}, 20-21$ Apr 2004, D. C. Werneke, N. K. Lujan, O. León, \& R. Pajua.

Paratypes. Venezuela, Amazonas, río Ventuari - río Orinoco drainage: ANSP 180214, 4 (1, 89.8 mm SL), AUM 39311, 71 (13, 73.1-98.9 mm SL), CAS 222236, 4 (1, 82.9 mm SL), CU 90879, 4 $(1,84.1 \mathrm{~mm} \mathrm{SL})$, FMNH 116464, 4 (1, $81.8 \mathrm{~mm} \mathrm{SL})$, MBUCV-V 32685, 4 (1, $80.4 \mathrm{~mm} \mathrm{SL})$, MCNG 51995, 4 (1, $80.2 \mathrm{~mm} \mathrm{SL})$, UF 148421, 4 (1, 87.0 mm SL), USNM 382415, 4 (1, 73.0 mm SL), río Manapiare $14.5 \mathrm{~km} \mathrm{NW}$ of San Juan de Manapiare, $05.42863^{\circ}$, $-066.13616^{\circ}, 12$ Apr 2004, N. K. Lujan, M. H. Sabaj, L. S. de Souza, \& D. C. Werneke. ANSP 180215, 4 (4, 83.7-93.8 mm SL), AUM 39505, 4 (4, 96.8-105.5 mm SL), and MCNG 51997, 3 (3, 68.5-75.5 mm SL), same data as Holotype. ANSP 180216, 1 , AUM 3928234 (28, 51.6-93.3 mm SL), MCNG 51998, 8, río Parucito at raudales Salomon $2.7 \mathrm{~km}$ NE of San Juan de Manapiare, $05.34637^{\circ},-066.03347^{\circ}, 16$ Apr 2004, D. C. Werneke, N. K. Lujan, \& O. León. ANSP 180217, 1, AUM 392398 (8, 69.5-125.53 mm SL), MCNG 51996, 2, río Ventuari bedrock outcrop $83 \mathrm{~km}$ ENE of Macuruco $153 \mathrm{~km}$ ENE of San Fernando de Atabapo, $04.25346^{\circ},-066.34466^{\circ}, 6$ Apr 2004, N. K. Lujan, D. C. Werneke, M. H. Sabaj, L. S. de Souza, \& O. León. ANSP 180223, 7, AUM 42211, 13, MCNG 52926, 7, río Ventuari near ornamental fish market in the river, $04.07565^{\circ},-066.89285^{\circ}, 3$ Apr 2005, N. K. Lujan, M. Arce, E. L. Richmond, M. B. Grant, \& T. E. Wesley. AUM 37979, 1 (1, 91.7 mm SL), río Guapuchi first major riffle complex, $04.11667^{\circ},-066.76667^{\circ}, 16$ April 2003, N. K. Lujan \& O. León. AUM 39541, 1 (1, 104.5 mm SL), río Ventuari at raudales Tencua $56 \mathrm{~km}$ ESE of San Juan de Manapiare, $05.04968^{\circ},-065.62722^{\circ}, 20$ Apr 2004, D. C. Werneke, N. K. Lujan, O. León, \& R. Pajua. UF 77850, 16 (5, 70.9-101.7 $\mathrm{mm}$ SL), 2 c\&s, río Ventuari at Tencua just below Tencua Falls, 20 Mar 1981, C. R. Gilbert and S. Reid.

Non-type material. VENEZUELA, Amazonas, río Casiquiare río Negro drainage: ANSP 180220, 3, AUM 42178, 4, MCNG 52927,3 , río Siapa rapids $154 \mathrm{~km}$ E of San Carlos de río Negro, $01.60339^{\circ},-065.71587^{\circ}, 11$ Mar 2005. ANSP 180221, 5, AUM 42183, 8, MCNG 52928, 5, río Siapa raudales Gallineta $142 \mathrm{~km} \mathrm{E}$ of San Carlos de río Negro, 01.81679 , -065.79473 ${ }^{\circ}, 17$ Mar 2005. ANSP 180222, 2, AUM 42200, 4, MCNG 52929, 1, río Casiquiare $153 \mathrm{~km}$ NE of San Carlos de río Negro, $02.79877^{\circ},-066.00652^{\circ}, 24$ Mar 2005. AUM 42129, 3, río Casiquiare bedrock in stream $73 \mathrm{~km}$ $\mathrm{NE}$ of San Carlos de río Negro, $02.35258^{\circ},-066.57521^{\circ}, 9 \mathrm{Mar}$ 2005. MCNG 26074, 1 (1, $92.4 \mathrm{~mm} \mathrm{SL})$, río Siapa 176 river km from the río Casiquiare, $01.41667^{\circ},-065.68333^{\circ}, 14$ Apr 1991. MCNG 26124, 1 (1, $94.8 \mathrm{~mm} \mathrm{SL})$, río Siapa from 10-15 km below coordinates, $01.50000^{\circ},-065.71667^{\circ}, 20$ Apr 1991. MCNG 37045 , 2 (2, 100.0-106.5 mm SL), base camp on río Siapa below raudal Gallineta, 11 Jan 1998. MCNG 37063, 1 (1, 83.7 mm SL), río Siapa 


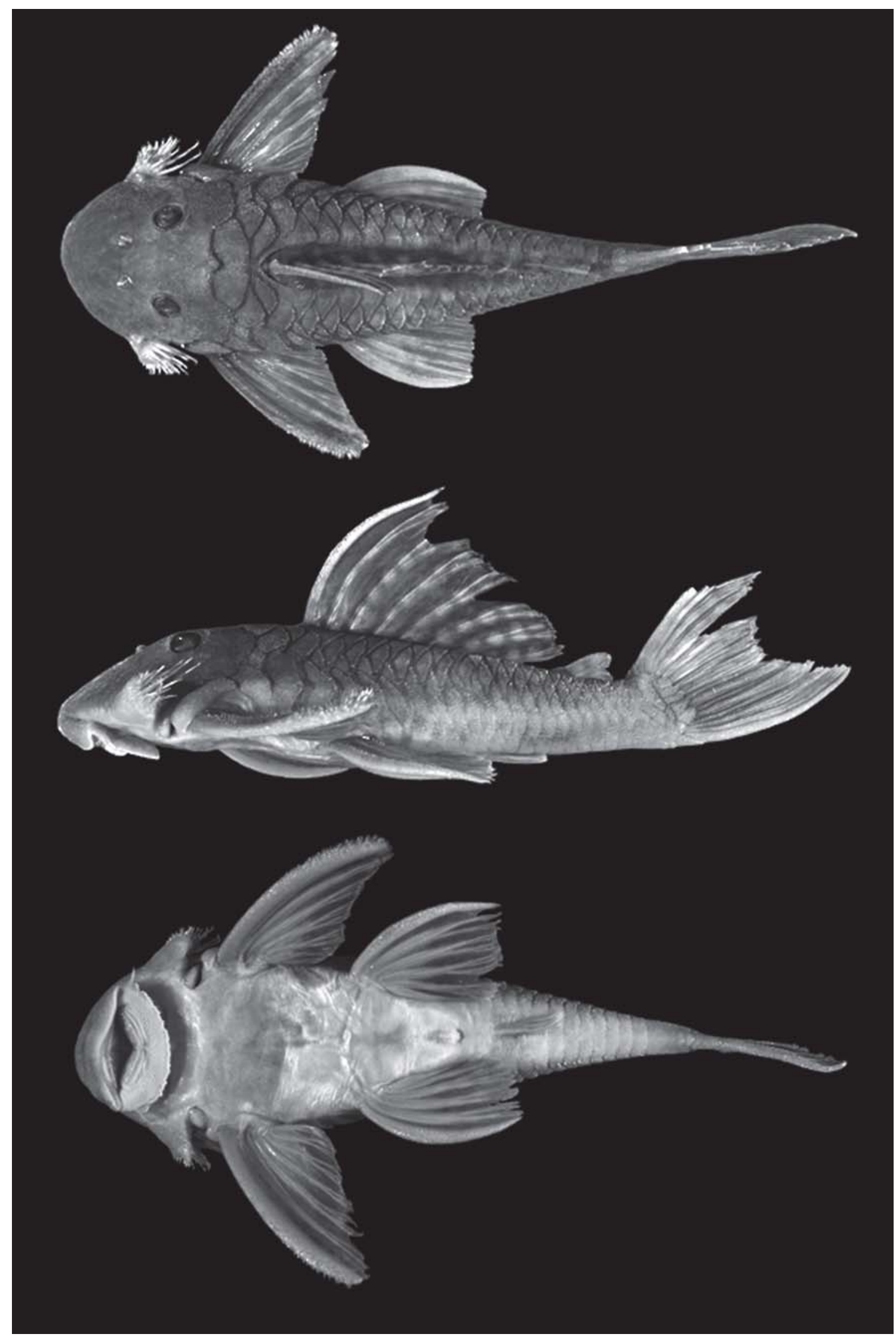

Fig. 2. Hemiancistrus guahiborum, MCNG 51994, 106.9 mm SL. Holotype, dorsal, lateral, and ventral views. Photos by D. C. Werneke. 
immediately below raudal Gallineta, $01.81667^{\circ},-065.78333^{\circ}, 14$ Jan 1998. MCNG 38319, 1 (1, $98.0 \mathrm{~mm} \mathrm{SL})$, base camp on río Siapa below raudal Gallineta, 11 Jan 1998. Río Orinoco drainage: ANSP 162173, 5 (9, 66.0-87.0 mm SL), 2 c\&s, río Orinoco at rocks circa $1 \mathrm{~km}$ above La Esmeralda, 14 Mar 1987. ANSP 162177, 26 (5, 33.4-38.6 mm SL), río Orinoco raudales de Atures at Culebra circa $7 \mathrm{~km} \mathrm{~S}$ of Puerto Ayacucho, 11 Nov 1985. ANSP 180218, 2, AUM 42116, 3, MCNG 52930, 1, río Orinoco 117 km W of La Esmeralda, $03.28998^{\circ},-066.60004^{\circ}, 29$ Mar 2005. ANSP 180219, 3, AUM 42123, 7, MCNG 52931, 3, río Orinoco $33.9 \mathrm{~km} \mathrm{~W}$ of La Esmeralda at Punto Piaroa, $03.14744^{\circ},-065.85381^{\circ}, 28$ Mar 2005. AUM 42093, 2, río Orinoco beach $16.1 \mathrm{~km}$ E of La Esmeralda, $03.15842^{\circ}$, $-06569482^{\circ}, 25$ Mar 2005. AUM 42103, 1, río Orinoco beach and bedrock outcropping $50 \mathrm{~km}$ E of San Fernando de Atabapo, $03.97029^{\circ},-067.25506^{\circ}, 2$ Mar 2005. AUM 42166, 1, río Orinoco bedrock outcrop $52.9 \mathrm{~km} \mathrm{SE}$ of San Antonio $102 \mathrm{~km}$ W of La Esmeralda, 03.10036 ${ }^{\circ},-066.46277^{\circ}, 4$ Mar 2005. AUM 42192, 2, río Orinoco Punto de Maraya $80.8 \mathrm{~km} \mathrm{~W}$ of San Fernando de Atabapo at Isla Maraya, $04.02303^{\circ},-066.97189^{\circ}, 31$ Mar 2005. AUM 42941, 2 (1, $69.6 \mathrm{~mm} \mathrm{SL})$, río Orinoco at Puerto Venado $4.3 \mathrm{~km} \mathrm{~S}$ of Samariapo 56,4 km SSW of Puerto Ayacucho, 05.21060 ${ }^{\circ}$, 067.80495 ${ }^{\circ}, 26$ Feb 2005. MCNG 25793, 6 (4, 58.4-86.1 mm SL), 1 c\&s, río Ocamo en raudal Arata, $03.13333^{\circ},-064.56667^{\circ}, 24$ Jan 1980. MCNG 47576, 2 (2, 93.5-107.4 mm SL), río Orinoco rocks near Macuruco, 23 Sep 2002. MCNG 47577, 1 (1, 122.3 mm SL), río Orinoco rocks near Macuruco, 23 Sep 2002. VENEZUELA, Bolivar, río Caura - río Orinoco drainage: ANSP 149689, 13 (5, 36.5-77.6 mm SL), Surapire Rapids on río Caura circa 2 hrs upstream from río Caura-río Nichare junction, 23 Jan 1977. MCNG 20878, 3 (5, 58.3-87.4 mm SL), 2 c\&s, río Nichare at a creek behind a small island, $06.22917^{\circ},-064.93861^{\circ}, 19$ Mar 1989. MCNG 22521, 3 (3, 53.3-91.0 mm SL), upper río Nichare, on a beach above caño Icutú, 06.81944ํ, -064.91667 15 Mar 1989. MCNG 22701, 5 (4, 75.9-114.8 mm SL), 1 c\&s, caño Tabaro tributary of río Nichare, $06.36667^{\circ},-064.96667^{\circ}, 21$ Mar 1989. MCNG 22795, 1 (1, 42.2 $\mathrm{mm}$ SL), caño Tabaro in a stream entering the Serrania, 22 March 1989. MCNG 22867, 7 (7, 49.8-83.1 mm SL), 1 c\&s, upper río Nichare, $06.87500^{\circ},-064.93417^{\circ}, 18$ Mar 1989. MCNG 22933, 1 $(1,70.6 \mathrm{~mm} \mathrm{SL})$, caño Tabaro to $3 \mathrm{~km}$ from río Nichare, $06.36667^{\circ}$, $-064.96667^{\circ}, 25$ Mar 1989. río Orinoco drainage: ANSP 162176, 2 (2, 51.9-105.3 mm SL), río Orinoco at El Burro, 06.20000, $067.43333^{\circ}, 26$ Nov 1985.

Diagnosis. Hemiancistrus guahiborum can be separated from all other Hemiancistrus and all Peckoltia except P. braueri and $P$. cavatica by having an orange edge to the dorsal and caudal fins (Fig. 1). Hemiancistrus guahiborum can be separated from the $H$. annectens group of Armbruster (1998) $(H$. annectens, H. aspidolepis, H. holostictus, H. maracaiboensis, $H$. panamensis, and $H$. wilsoni), $H$. fuliginosus, $H$. hammarlundi, $H$. landoni, $H$. medians, $H$. megalopteryx, $H$. micrommatos, H. punctulatus, H. spilomma, H. spinosissimus, P. oligospila, P. sabaji, and P. snethlagae by having large tan blotches on a dark body with the blotches sometimes faded so that the body is entirely dark ( $v s$. with black spots); from $H$. chlorostictus and $H$. votouro by having large light blotches (vs. small white spots); from $H$. chlorostictus, H. meizospilos, and $H$. votouro by having a forked caudal fin (vs. an emarginate caudal fin); from $H$. macrops by having the white markings diffuse ( $v s$. discreet spots); from the $H$. annectens group
Table 1. Morphometrics of Hemiancistrus guahiborum $(\mathrm{N}=$ 124). 'Landmarks' indicate the two points between which the measurements were taken (from Armbruster, 2003). Measurements are ratios of SL (predorsal 1. to pelvic-dorsal 1.) or head 1. (head-eye 1. to premaxillary tooth cup 1.).

\begin{tabular}{clccr}
\hline Landmarks Measurement & Mean & SD & \multicolumn{1}{c}{ Range } \\
\hline $1-20$ & SL (mm) & 78.1 & 18.2 & $33.4-125.5$ \\
$1-10$ & Predorsal L & 43.3 & 1.8 & $39.6-50.6$ \\
$1-7$ & Head L & 36.4 & 1.4 & $32.7-42.2$ \\
$7-10$ & Head-dorsal L & 7.2 & 1.0 & $4.9-10.1$ \\
$8-9$ & Cleithral W & 29.4 & 2.7 & $6.8-35.3$ \\
$1-12$ & Head-pectoral L & 28.0 & 1.2 & $23.6-31.2$ \\
$12-13$ & Thorax L & 22.8 & 1.8 & $10.2-26.0$ \\
$12-29$ & Pectoral-spine L & 32.6 & 2.3 & $26.1-38.7$ \\
$13-14$ & Abdominal L & 22.7 & 1.4 & $19.1-27.4$ \\
$13-30$ & Pelvic-spine L & 26.5 & 1.9 & $22.6-38.6$ \\
$14-15$ & Postanal L & 33.5 & 1.4 & $29.9-39.3$ \\
$14-31$ & Anal-fin spine L & 11.2 & 1.2 & $7.2-14.0$ \\
$10-12$ & Dorsal-pectoral D & 27.8 & 1.3 & $24.6-31.4$ \\
$10-11$ & Dorsal spine L & 33.4 & 2.9 & $21.7-43.3$ \\
$10-13$ & Dorsal-pelvic D & 21.9 & 2.4 & $13.5-28.6$ \\
$10-16$ & Dorsal-fin base L & 32.6 & 2.4 & $20.3-37.9$ \\
$16-17$ & Dorsal-adipose D & 9.4 & 1.8 & $5.0-14.8$ \\
$17-18$ & Adipose-spine L & 10.9 & 1.9 & $6.1-18.5$ \\
$17-19$ & Adipose-up. caudal D & 16.8 & 2.7 & $11.2-25.9$ \\
$15-19$ & Caudal peduncle Dp & 11.9 & 1.1 & $8.8-14.2$ \\
$15-17$ & Adipose-low. caudal D. & 23.8 & 1.9 & $20.1-30.3$ \\
$14-17$ & Adipose-anal D & 19.2 & 1.6 & $13.7-22.2$ \\
$14-16$ & Dorsal-anal D & 15.8 & 1.2 & $11.6-19.3$ \\
$13-16$ & Pelvic-dorsal D & 28.7 & 2.6 & $20.7-34.8$ \\
$5-7$ & Head-eye L & 29.8 & 2.8 & $24.3-39.1$ \\
$4-5$ & Orbit Dia & 19.0 & 1.6 & $15.6-22.6$ \\
$1-4$ & Snout L & 64.5 & 2.8 & $54.7-70.0$ \\
$2-3$ & Internares W & 13.0 & 2.8 & $8.5-22.5$ \\
$5-6$ & Interorbital W & 30.4 & 4.0 & $25.5-44.6$ \\
$7-12$ & Head Dp & 67.1 & 4.0 & $46.6-80.2$ \\
$1-24$ & Mouth L & 49.5 & 3.5 & $38.7-58.1$ \\
$21-22$ & Mouth W & 54.4 & 4.3 & $22.5-63.5$ \\
$22-23$ & Barbel L & 17.9 & $4.8-14.2$ \\
$25-26$ & Dentary tooth cusp L & 1.8 & $12.9-21.9$ \\
$27-28$ & Premax. tooth cusp L & 1.6 & $12.9-22.1$ \\
\hline & & &
\end{tabular}

by having more than 10 relatively straight hypertrophied odontodes on the evertible cheek plates ( $v s$. usually less than five strongly recurved hypertrophied odontodes); and from the remainder of Peckoltia by having the dorsal fin with light spots or uniformly colored and the sides either solidly colored or with tan blotches (vs. dorsal fin with bands or dark spots and sides with saddles dorsally).

In addition Hemiancistrus guahiborum can be separated from all ancistrins except Baryancistrus, other Hemiancistrus, Hypancistrus, Panaque, Parancistrus, Peckoltia, and some Pseudancistrus by lacking odontodes on the opercle; from Ancistrus, Dekeyseria, Lasiancistrus, Neblinichthys, and Pseudolithoxus by having five rows of plates on the caudal peduncle ( $v s$. three); from Hopliancistrus by having more than five hypertrophied odontodes on the evertible cheek plates; from Exastilithoxus and Lithoxus by having 28 or more teeth per jaw ramus (vs. 10 or fewer) and oval lips (vs. round); from Acanthicus, Chaetostoma, Cordylancistrus, Dolichancistrus, Leptoancistrus, Leporacanthicus, Megalancistrus, and Pseudacanthicus by having seven dorsal-fin rays (vs. eight or more); from Acanthicus, Dekeyseria, 
Leporacanthicus, Megalancistrus, and Pseudacanthicus by lacking keels on the lateral plates; from most Pseudancistrus by lacking hypertrophied odontodes around the snout; from Pseudancistrus sidereus and P. megacephalus by having diffuse spots when present (vs. round spots); from Baryancistrus by not having the posterior portion of the dorsal-fin membrane expanded; from Parancistrus, Spectracanthicus, and most Baryancistrus by not having the dorsal fin connected to the adipose fin; from Panaque by having viliform teeth ( $v s$. spoon-shaped teeth or elongated teeth); and from Hypancistrus by having the teeth of the dentary and premaxillary of equal size ( $v s$. dentary teeth longer than premaxillary teeth).

Description. Member of Hypostominae, Ancistrini as diagnosed by Armbruster (2004). Morphometrics in Table 1. Medium-sized loricariids, largest specimen $125.5 \mathrm{~mm}$ SL. Body stout. Head sloped at $45^{\circ}$ angle to point above anterior portion of eye. Nape ascending slightly to insertion of dorsal fin. Dorsal slope decreasing to insertion of dorsal procurrent caudal rays then ascending to caudal fin. Body depth greatest below anterior insertion of dorsal fin. Ventral profile flat to caudal fin. Caudal peduncle triangular in cross section with dorsal surface slightly rounded. Body widest at insertion of pectoral fins, narrowest at insertion of caudal fin. Snout rounded.

Eyes moderately sized. Interorbital space flat. Slight ridge formed between anterodorsal margin of orbit and nares. Supraoccipital pointed posteriorly, not elevated above nuchal plate. Infraorbitals, frontal, nasal, pterotic-supracleithrum, and supraoccipital supporting odontodes. Preopercle and opercle not supporting odontodes.

Lips covered with short, wide papillae. Lower lip wide, upper lip narrow. Maxillary barbel only barbel present, reaching one third of distance to gill opening. Iris with small dorsal flap.

Medial plates 22-26 (mode $=24)$. Plates unkeeled. Five caudal peduncle plate rows. Plates on all surfaces of body except for anteroventral margin of snout, throat, and abdomen from pectoral girdle to anus. Some small embedded plates ventral to pectoral girdle and along ventromedial insertion of pectoral fin. Evertible cheek plates supporting hypertrophied odontodes that can be everted perpendicular to head. Cheek odontodes 9-84 $($ mode $=45)$; number of cheek odontodes increases ontogenetically. Longest evertible cheek odontode reaching cleithrum. Hypertrophied cheek odontodes relatively weak. Moderately hypertrophied odontodes present along dorsal-, adipose-, pelvic-, caudal-, and pectoral-fin spines; larger individuals with hypertrophied odontodes at tip of pectoral spine.

Dorsal fin II,7; dorsal-fin spinelet V-shaped, dorsal-fin locking mechanism present, dorsal fin free from adipose fin, distal margin of dorsal fin reaching insertion of adipose spine when adpressed. Adipose fin with single preadipose plate and moderately long spine. Caudal fin i,14,i; caudal fin forked, lower lobe longer than upper, dorsal and ventral procurrent caudal rays four to five (mode four). Pectoral fin I,6; pectoral-fin

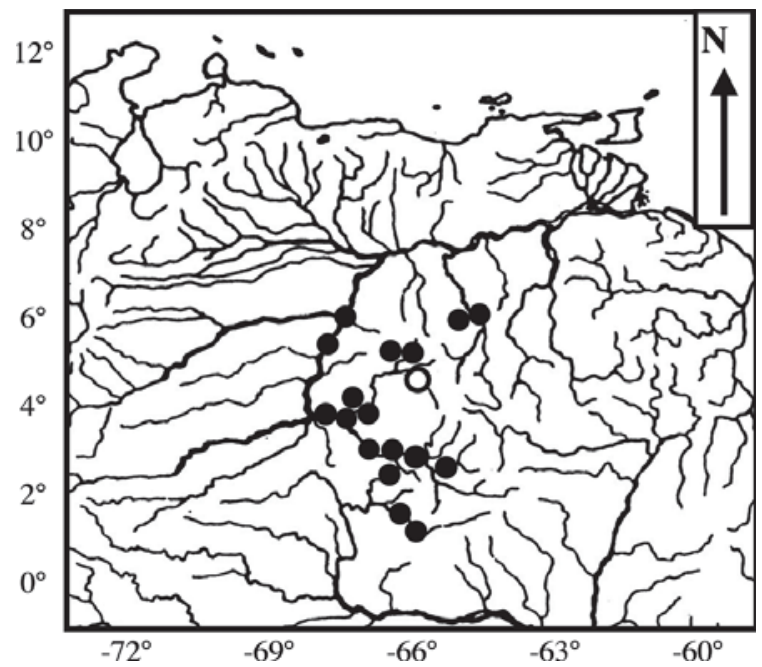

Fig. 3. Range of Hemiancistrus guahiborum. Open symbol indicates type locality.

spine reaching beyond insertion of pelvic-fin spine when adpressed ventral to pelvic fin. Pelvic fin I,5; adpressed pelvic-fin spine extending beyond base of anal fin. Anal fin I,4; anal-fin spine slightly shorter than first ray.

Teeth bicuspid with median lobe one third longer and twice as wide as lateral lobe. Worn teeth with lobes approaching equal lengths. $30-64$ left dentary teeth $($ mode $=43) .28-72$ left premaxillary teeth $($ mode $=39)$.

Color in Life. Base color of head and body mottled gray and tan, with dermal plates outlined with dark gray. Pattern irregular and varies among individuals, but between and behind eyes tan spots are smaller and rounded. Behind dorsal fin, upper half of flank gray with irregular tan blotches, lower half of flank mostly tan. Lips tan. Eye light reddish-brown. Dorsal fin with smoky charcoal membranes, spine gray on anterior margin but tan laterally, not spotted; rays with series of gray and tan blotches, more or less aligned to form alternating rows with three or four gray blotches of each contrasting color; fin edged with very thin margin of brick red or orange, wider on first three or four rays. Adipose fin tan with distal gray edge. Caudal-fin rays dark gray, membranes in between transparent, basal plate on base of fin gray; distal margin edged with orange, widest on upper rays. Pectoral fin spine gray, rays tan, sometimes spotted. Pelvic-fin spine and rays tan on distal two thirds of fin, dark gray on distal third. Abdomen tan to cream.

Color in alcohol. Base color brown or gray (Figs. 1-2). Small faint light gray-tan spots on head, becoming larger and more irregularly shaped on body. Sizes of spots vary between individuals and absent in some specimens. Dorsal-fin spine lacking spots. Dorsal-fin rays and membranes typically with spots, spots on dorsal-fin membranes difficult to discern in some specimens. Adipose-fin spine with only one or two spots if present, membrane dusky. Caudal fin dusky, occasionally with lighter narrow bands in some specimens. Pec- 
toral and pelvic fins sometimes with spots dorsally, rays and membranes lacking spots dusky. Anal fin dusky near insertion, fading distally. Lips, barbels, and throat tan. Small embedded plates below pectoral girdle gold. Venter behind pectoral girdle to anus translucent white, internal musculature and organs visible through skin. Venter behind anus tan with scattered melanophores.

Range. Found in middle and upper río Orinoco and its tributaries including the río Caura, río Ventuari, and río Ocamo, also found in río Casiquiare (Fig. 3).

Etymology. Named for the Guahibo, a tribe of people inhabiting parts of southern Venezuela and western Colombia for the help some members of the tribe provided in collecting specimens in the upper río Ventuari.

Gut Morphology and Ecology. Gastrointestinal tract brown with yellow fat deposits loosely attached to intestinal wall with viscera packed tightly into peritoneal cavity. Esophagus turns $90^{\circ}$ to right upon entering the peritoneal cavity, extends short distance ( $\sim 10 \mathrm{~mm}$ in specimens examined), then turns $90^{\circ}$ to posterior before transitioning into stomach. Stomach extends straight to posterior for two thirds of total stomach length then turns $180^{\circ}$ to right for final one third. Length of stomach $15 \mathrm{~mm}$. Volume of stomach highly variable. From stomach, intestines turn $90^{\circ}$ to left, crossing dorsally over esophagus, then turn $90^{\circ}$ to posterior, continuing towards anus. Proximal and distal portions of intestine spiral clockwise in parallel, with coils accruing ventral to stomach. Total length of intestines plus stomach ranged from 15-18 times SL. External diameter of intestines ranged from $1.0-1.5 \mathrm{~mm}$.

Hemiancistrus guahiborum were most frequently encountered in cracks and interstitial spaces of granitic and lateritic rocks in flow. Gut contents of all individuals consisted largely of small grained $(<0.001 \mathrm{~mm}$ diameter) mineral matrix. Identifiable organic material embedded in the gut matrix of three individuals surveyed was limited to midge larvae (Chironomidae, $\mathrm{n}=3$ ), a fly pupa (Diptera, $\mathrm{n}=1$ ), an unidentified insect exoskeleton $(n=1)$, and a shed tooth $(n=1)$.

\section{Discussion}

Hemiancistrus guahiborum is one of the most common ancistrins in the upper Orinoco River basin. It is found in both granitic and lateritic rocky habitats with flow, where it was caught in abundance. Hemiancistrus guahiborum feeds by scraping periphyton and ingesting both the sediment matrix deposited from the water column, and attached algae and benthic macroinvertebrates. Other loricariids commonly collected with $H$. guahiborum were Hypostomus squalinus, Hemiancistrus subviridis, Peckoltia sabaji, and P. aff vittata. Although the range of $H$. guahiborum encompasses a region where loricariids are intensively harvested for the ornamental fish trade and it is one of the most abundant loricariids in the area, it is not commonly exported. Despite its often quite at- tractive appearance when alive, it is typically passed over by fishermen seeking the more strikingly colored species with which it is sympatric.

\section{Acknowledgements}

This project represents part of Planetary Biodiversity Inventory: All Catfish Species (Siluriformes) - Phase I of an Inventory of the Otophysi, a five year grant through the US National Science Foundation to describe all species of catfishes (NSF DEB-0315963) and NSF grant DEB-0107751 to JWA. We would like to express our deepest appreciation to O. León for his invaluable help in obtaining permits, logistical support, and aiding in fieldwork. Additional thanks to M. Arce, R. Betancur, A. Luna, R. Pajua, L. deSouza, T. Wesley, M. Grant, E. Richmond, J. Valadez, D. Brooks, F. Brito, and O. Santa Ella for aid in collecting specimens. Thanks to R. Robbins at UF and M. Sabaj at ANSP for loan materials.

\section{Literature Cited}

Armbruster, J. W. 1998. Modifications of the digestive tract for holding air in loricariid and scoloplacid catfishes. Copeia, 1998: 663-675.

Armbruster, J. W. 2003. Peckoltia sabaji, a new species from the Guyana Shield (Siluriformes: Loricariidae). Zootaxa, 344: 1-12.

Armbruster, J. W. 2004. Phylogenetic relationships of the suckermouth armoured catfishes (Loricariidae) with emphasis on the Hypostominae and the Ancistrinae. Zoological Journal of the Linnean Society, 141: 1-80.

Armbruster, J. W. \& D. C. Werneke. 2005. Peckoltia cavatica, a new loricariid catfish from Guyana and a redescription of P. braueri (Eigenmann 1912) (Siluriformes). Zootaxa, 882: 1-14.

Cardoso, A. R. \& P. H. F. Lucinda. 2003. Three new species of Hemiancistrus (Teleostei: Siluriformes: Loricariidae) from the rio Tocantins basin with comments on the genus. Ichthyological Exploration of Freshwaters, 14: 73-84.

Leviton, A. E., R. H. Gibbs Jr., E. Heal \& H. E. Dawson. 1985. Standards in herpetology and ichthyology: Part I. Standard symbolic codes for institutional resource collections in herpetology and ichthyology. Copeia, 1985(3): 802-832.

Schaefer, S. A. 1997. The neotropical cascudinhos: systematics and biogeography of the Otocinclus catfishes (Siluriformes: Loricariidae). Proceedings of the Academy of Natural Sciences of Philadelphia, 148: 1-120.

Taylor, W. R. \& G. C. Van Dyke. 1985. Revised procedures for staining and clearing small fishes and other vertebrates for bone and cartilage study. Cybium, 9: 107-119.

Received July 2005

Accepted November 2005 